\title{
PERAN GURU DALAM PENANGANAN PERILAKU ANAK HIPERAKTIF DI TK NEGERI 1 SAMARINDA
}

\author{
Fachrul Rozie, Dita Safitri, Wiwik Haryani \\ Universitas Mulawarman Samarinda \\ corresponding e-mail: fachrulrozie@fkip.unmul.ac.id
}

\begin{abstract}
The purpose of research is to know: the role of teachers in handling hyperactive child behavior in TK Negeri Pembina 1 Samarinda, the inhibiting factor of teacher in the handling of hyperactive child behavior in TK Negeri Pembina 1 Samarinda, and supporting factor of teacher in handling behaviour of hyperactive children. This method of research is qualitative with a case study approach consisting of two focuses, namely the role of the teacher and child behavior hyperactivity. The results show that hyperactive child behavior has difficulties to focus, unable to sit quietly, perform unmistakable, rebellious activities and could not wait. The teacher's role in child care is hyperactive: as a learning designer, learning artist, learning motivator, mediator learning and inspirational learning. The inhibitory factor in treating hyperactive children is the professionalism of teachers, approaches with hyperactive children, and child behavior. The supporting factors, namely environment, facilities and infrastructure.
\end{abstract}

Keywords: role of teachers, child behavior, hyperactivity

\begin{abstract}
Abstrak
Tujuan penelitian ini untuk mengetahui: peran guru dalam menangani perilaku anak hiperaktif di TK Negeri 1 Pembina Samarinda, faktor penghambat peran guru dalam penanganan perilaku anak hiperaktif di TK Negeri 1 Samarinda, dan faktor pendukung peran guru dalam penanganan perilaku anak hiperaktif di TK Negeri 1 Samarinda. Metode penelitian ini adalah kualitatif dengan pendekatan studi kasus yang terdiri dari dua fokus, yakni peran guru dan perilaku anak hiperaktif. Hasil penelitian menunjukkan bahwa perilaku anak hiperaktif mengalami kesulitan untuk memusatkan perhatian, tidak dapat duduk tenang, melakukan kegiatan tanpa tujuan yang jelas, suka memberontak dan tidak bisa sabar dalam menunggu. Peran guru dalam penanganan anak hiperaktif yaitu: Sebagai desainer pembelajaran, seniman pembelajaran, motivatior pembelajaran, mediator pembelajaran dan inspirator Pembelajaran. Adapun faktor penghambat dalam menangani anak hiperaktif ialah profesionalisme guru, pendekatan dengan anak hiperaktif, dan perilaku anak. Faktor pendukungnya, yaitu lingkungan, sarana dan prasarana.
\end{abstract}

Kata Kunci: peran guru, perilaku anak, hiperaktif 


\section{Pendahuluan}

Pendidikan adalah usaha sadar yang dilakukan oleh keluarga, masyarakat dan pemerintah, melalui kegiatan bimbingan, pengajaran, dan latihan yang berlangsung di sekolah maupun di luar sekolah. Taman Kanak-kanak (TK) merupakan salah satu bentuk Pendidikan Anak Usia Dini pada jalur pendidikan formal yang menyelenggarakan program pendidikan bagi anak usia 4 sampai 6 tahun dengan bertujuan membantu anak didik mengembangkan berbagai potensi seperti fisik, moral, nilai-nilai bahasa, motorik, dan seni untuk siap memasuki pendidikan dasar. Salah satu masalah dalam perkembangan anak yang harus diketahui guru TK dan pendidik lainnya adalah masalah perkembangan anak yang bersifat non-normatif atau perilaku menyimpang. Guru TK sebagai pendidik yang ideal harus memiliki kemampuan profesional sesuai dengan standar yang ditetapkan, semestinya juga membekali diri dengan berbagai wawasan dan pengetahuan tentang anak-anak didiknya.Pendidik dituntut untuk dapat mengenali setiap ciri masalah dalam perkembangan anak yang mengalami kesulitan, sehingga dapat memberikan penanganan yang tepat. Akan sangat berbahaya bila salah dalam mengidentifikasi masalah perkembangan anak, misalnya anak autis dianggap anak hiperaktif sehingga penanganan yang diberikan juga tidak akan tepat pada sasaran. Alih-alih anak akan terbebas dari masalahnya dengan berkembang baik justru masalah yang dialami oleh anak akan semakin parah.

Anak dengan berkebutuhan khusus adalah anak yang secara signifikan mengalami kelainan atau penyimpangan dalam proses pertumbuhan kembangnya dibandingkan anak-anak lain yang seusia sehingga mempunyai kekhususan dari segi kebutuhan layanan kesehatan, kebutuhan pendidikan khusus, pendidikan layanan khusus, pendidikan inklusi, dan kebutuhan akan kesejahteraan sosial dan bantuan sosial. Salah satunya ialah perilaku hiperaktif. Aktifitas anak yang tidak lazim dan cenderung berlebihan yang ditandai dengan gangguan perasaan gelisah, selalu menggerak-gerakkan jari-jari tangan, kaki, tidak dapat duduk dengan tenang dan selalu meninggalkan tempat duduknya meskipun pada saat dimana dia seharusnya duduk dengan tenang. Terminologi lain yang dipakai mencakup beberapa kelainan perilaku meliputi perasaan yang meluap-luap, aktifitas yang berlebihan, suka membuat keributan, membangkang dan destruktif yang menetap.

Hasil penelitian dilakukan oleh Suharmini (2005) dapat diketahui bahwa ada beberapa faktor yang dapat mempengaruhi prilaku hiperaktif pada anak yaitu: kurangnya pengawasan, suasana keluarga, penokohan, dan kemiskinan. Faktorfaktor menjadi penyebab seseorang anak menjadi kecenderungan berperilaku hiperaktif yang menunjukkan karakter arogan serta menyukai kekerasan sebagai bentuk mengekspresikan yang diinginkan. 
Sebagaimana hasil penelitian dari Liana, dkk (2018) mendeskripsikan bahwa pembelajaran menggunakan model percontohan pada anak usia mampu menstimulasi tumbuhnya karakter yang positif melalui peran guru di kelas saat pembelajaran berlangsung. Senada dari hasil penelitian tersebut dapat dipahami bahwa peran guru dalam mencontohkan perilaku yang positif pada anak usia dini mampu memberikan stimulasi pada tumbuh kembang karakter anak, karena anak usia dini belajar melalui segala objek yang dapat di amati.

Keterlibatan anak usia dini pada aktivitas pembelajaran sangat perlu sebagai upaya pengembangan perkembangan yang dimiliki. Sebagaimana hasil penelitian dari Farny, dkk (2016) menjelaskan bahwa bimbingan pada anak usia dini dengan melibatkan emosi serta afeksi penuh kasih sayang mampu mengembangkan aspek emosi pada anak usia dini. Sehingga dapat diketahui bahwa peran guru perlu memberikan perhatian lebih pada anak usia dini yang memiliki perilaku hiperaktif di kelas.

Peneliti melakukan studi awal dan menemukan anak berperilaku hiperaktif yaitu, $\mathrm{Rj}$ dan Ar. Perilaku hiperaktif yang ditunjukkan oleh kedua anak tersebut adalah ketidakmampuan anak dalam berkonsentrasi hanya kurang dari 1 menit, mondar-mandir di dalam kelas, banyak melakukan gerakan tangan dan kaki yang berlebihan, berlarian tanpa arah, bermain dan berbicara sendiri, dan keluar masuk kelas tanpa alasan. Anak yang mengalami perilaku hiperaktif akan mengalami permasalahan baik fisik maupun psikolosgis.

Berbagai penanganan dapat dilakukan untuk mengendalikan perilaku hiperaktif. Salah satunya dapat dengan cara menstimulasi yang dapat dilakukan oleh guru stimulasi di sekolah atau terapi yang dapat dilakukan oleh ahli terapi. Seperti yang ada di TK Negeri 1 Samarinda, tersedianya ruang khusus untuk menstimulasi anak-anak berkebutuhan khusus dimana terdapat beberapa alat bantu untuk menstimulasi anak tersebut. Sedangkan dikelas anak dapat dipantau dan diajarkan oleh guru pendamping kelas yang memang khusus untuk menjaga anak hiperaktif. Namun untuk mendapatkan hasil yang lebih maksimal harus tetap dengan kerjasama antara kedua orang tua anak, guru stimulasi, guru pendamping dan ahli terapi.

Sehingga pembatasan dalam lingkup penelitian ini adalah pada peran guru dalam menangani anak berperilaku hiperaktif serta berbagai faktor pendukung dan penghambat yang dirasakan guru dalam menangani anak berperilaku hiperaktif. 


\section{Metode}

Jenis penelitian dalam penelitian ini adalah penelitian kualitatif (qualitative research) dengan metode studi kasus. Penelitian ini dilakukan pada tahun ajaran 2016/2017 pada semester genap di TK Negeri 1 Samarinda. Adapun teknik pengumpulan data tersebut adalah teknik observasi (pengamatan), interview (wawancara) dan dokumentasi yang dilakukan selama proses pembelajaran berlangsung di lokasi penelitian. Data yang telah terkumpul, kemudian di analisis menggunakan model analisis interaktif dari Milles \& Hubberman yaitu tahap reduksi data, display data, dan penarikan kesimpulan.

\section{Hasil dan Pembahasan}

Pada bab ini penulis akan menjelaskan hasil penelitian beserta pembahasanya. Berdasarkan hasil penelitian dapat dijelaskan tentang perikalu anak hiperaktif, peran guru dalam menangani anak hiperaktif dan faktor penghambat dan pendukung dalam menangani snak hiperaktif, dengan penjelasan sebagai berikut:

1. Perilaku Anak Hiperaktif

Anak hiperaktif merupakan perilaku yang berkembang secara tidak sempurna dan timbul pada anak-anak dan orang dewasa. Perilaku yang dimaksud seperti tidak fokus, sifat menentang, destruktif, tidak mengenal lelah, tanpa tujuan jelas, dan bukan penyabar yang baik dan usil. Jika anak menunjukkan lebih dari satu dari karakteristik perilaku tersebut maka anak tersebut termasuk sebagai anak hiperaktif. Berdasarkan observasi yang peneliti lakukan pada Ar dan Rj menunjukkan samasama tidak mampu fokus selama di dalam kelas, selalu bergerak kesana kemari tanpa memperdulikan teman-teman yang lain sedang mendengarkan atau melakukan kegiatan pembelajaran. Hal ini sesuai dengan dari hasil penelitian Suharmini (2005) yang menyebutkan kegiatan yang sedang anak hiperaktif lakukan tidak bisa bertahan lama. Anak hiperaktif tidak bisa bertahan diam lebih dari 5 menit, anak juga suka berteriak-teriak tidak jelas, kadang berlari naik keatas meja dan memanjat, sulit bermain dengan permainan yang membutuhkan konsentrasi yang lama dan berbicara semaunya. Juga memiliki sikap yang tidak mudah dipahami.

2. Peran Guru dalam Menangani Anak Hiperaktif

Peran seorang guru sebagaimana tercantum dalam permendikbud Nomor 137 dan 146 Tahun 2014, guru sebagai desainer pembelajaran, seniman pembelajaran, mediator pembelajaran, motivasi pembelajaran dan inspirator pembelajaran. Dari kelima peran tersebut, terdapat beberapa peran yang belum mampu terlaksana, yaitu dalam mediator. Selain itu, komunikasi serta pendekatan terhadap anak hiperaktif harus senantiasa dikembangkan guna untuk mengenal lebih dalam terkait dengan anak hiperaktif yang membutuhkan penanganan. Ketika kegiatan tertentu 
anak akan mendapat perlakuan khusus, biasanya diawal guru kelas akan memberitahu jika Ar dan Rj masih membutuhkan bantuan untuk beberapa hal. Seperti saat baris berbaris, Ar dan Rj harus mendapatkan perhatian khusus dengan cara didampingi tepat disamping atau dibelakang mereka. Karena pada saat perhatian anak teralihkan guru bisa segera membuat anak kembali fokus.

Cara belajar anak hiperaktif juga harus melalui dengan pembiasaan dan pengulangan. Pembiasaan yang dilakukan secara terus menerus dapat membuat anak menjadi mengenal, mengetahui dan ingat apa-apa saja yang harus ia lakukan. Terutama dalam pembiasaan pemberian reward dan punishment pada anak usia dini. Hasil ini sesuai dengan pendapat Sugiarmin dalam Baihaqi (2008:68), yaitu: 1) Menghilangkan atau mengurangi tingkah laku yang tidak dikehendaki. 2) Mengembangkan tingkah laku yang dikehendaki. Upaya dalam mengembangkan tingkah laku yang dikehendaki dilakukan dengan cara memberikan penguatan (reinforcement).

\section{Faktor Penghambat dan Pendukung Dalam Menangani Anak Hiperaktif}

Beberapa faktor yang sering dialami oleh guru ketika menangani anak hiperaktif yang pertama adalah profesionalisme guru. Pada awal menangani anak hiperaktif agak sulit karena kemampuan dasar Ibu Dh dan Ibu Kk bukanlah untuk menangani anak hiperaktif. Karena itu selama melakukan proses penanganan perilaku anak hiperaktif, terkadang guru masih terlihat kerepotan dan tanpa sadar guru sering kali terlihat tidak bisa mengontrol emosinya. Hasil observasi yang peneliti lakukan menunjukkan bahwa Ibu Dh dan Ibu Kk mempunyai kepribadian yang berbeda. Namun keduanya memiliki tanggung jawab yang sama dalam melakukan penaganan pada Ar dan Rj. Perlakuan yang mereka berikan pada Ar dan Rj tidak jauh berbeda dengan perlakuan yang mereka lakukan pada anak-anak lain. Ketika Ar dan Rj melakukan kesalahan, maka Ar dan Rj tetap ditegur, jika Ar dan Rj tidak mau merapikan mainan juga anak ditegur oleh Ibu Kk dan Ibu Dh. Hasil observasi lain menunjukkan bahwa metode pembelajaran untuk anak hiperaktif dan anak regular yang digunakan masih sebatas demonstrasi, dan penugasan. Selain itu guru juga tidak membuat program individu untuk anak hiperaktif walaupun mereka menganggap itu penting.

Penyebab utama sulitnya menangani anak hiperaktif adalah sifat mereka yang tidak mau diam, dan tidak bisa diberitahu jika hanya sekali saja. Faktor penghambat selanjutnya adalah pendekatan dengan anak hiperaktif, Ibu dh dan Ibu Kk belum pernah kontak langsung dengan anak hiperaktif selain dengan Ar dan $\mathrm{Rj}$, ini menimbulkan kesulitan tersendiri terlebih guru tersebut belum pernah mengikuti pelatihan terkait dengan pendidikan inklusi. Seperti yang dikatakan oleh Ibu Dh, bahwa Ibu Dh baru kali ini memegang anak hiperaktif. Jadi ketika diawal Rj masuk 
ada sedikit kesulitan, $\mathrm{Rj}$ sangat senang berlarian ke sana kemari dan anak hiperaktif akan sulit untuk diberitahu.

\section{Simpulan}

Berdasarkan hasil penelitian dan pembahasan dalam mendeskripsikan peran guru dalam menangani anak hiperaktif di TK Negeri 1 Samarinda, maka dapat ditarik simpulan bahwa peran guru dalam menangani anak berperilaku hiperaktif belum maksimal di TK Negeri 1 Samarinda. Hal ini terjadi karena kemampuan dasar guru dalam menangani anak berperilaku hiperaktif belum tercapai dengan baik. Faktor yang menjadi penghambat dalam menangani anak hiperaktif, yaitu : 1) Profesionalisme Guru dalam mengatur emosi masih kurang, 2) Pendekatan dengan Anak Hiperaktif karena kurangnya pengetahuan tentang anak hiperaktif, dan 3) Perilaku Anak yang tidak mau diam, dan tidak bisa diberitahu sekali. Sedangkan faktor pendukungnya, yaitu : 1) Lingkungan disekitar anak dapat mendukung dan berkerjasama dengan baik, 2) Sarana dan Prasarana sudah memadai dan adanya ruang stimulasi untuk anak hiperaktif.[]

\section{Daftar Rujukan}

Amin, Rasmi. (2019). "Prilaku Hiperaktif dan Upaya Penangannya", http://www.lpmpsulsel.net/v2/index.php?option=com_contentsEview=acticleE $\operatorname{id}=19$ 6:hiperaktifEcatid=42: widyaiswaraEitemid $=206$.

Asolihin. (2012). "Pengertian dan Konsep Dasar PAUD" (online), http://paudanakbermainbelajar.blogspot.co.id/2012/11/pengertian-dan-konsep-dasarpaud.html?m=1. diakses tanggal 14 Maret 2017.

Baihaqi \& M. Sugiarmin. (2008). Memahami dan Membantu Anak ADHD. Bandung: PT Refika Aditama

Boeree, George. (2010). Metode Pembelajaran dan Pengajaran. Yogyakarta: Ar-Ruzz Media.

Dayu, P. A. (2013). Mendidik Anak ADHD (Attention Deficit Hyperactivity Disorder). Yogyakarta: Javalitera

Dwi. (2016). "Pengertian Peran Secara Umum" (online), http://umumpengertian.blogspot.co.id/2016/06/pengertian-peran-secara-umum.html? $m=1$

Diakses tanggal 15 Maret 2017.

Fadilah, M. et al. (2014). Edutaiment Pendidikan Anak Usia Dini. Jakarta: Kencana.

Hadis, Abdul. (2006). Pendidikan Anak Berkebutuhan Khusus Autistik. Bandung Alfabeta.

Jafar, F. S., S. Syamsuddin., \& S. Sukaena. (2016). “A Descriptive Study of the Effectiveness of Parenting Against Early Childhood Social Development", 3rd International Conference on Early Childhood Education (ICECE 2016). 
Kosasih, E. (2012). Cara Bijak Memahami Anak Berkebutuhan Khusus. Bandung: YramaWidya

Liana, H., B. Rahardjo., \& H. Sjamsir. (2018). “Implementasi pembelajaran karakter anak usia dini di paud anak kita preschool samarinda", Pendas Mahakam: Jurnal Pendidikan Dasar, Vol. 3, No. 1.

Ma'mur, Jamal. (2014). Tips Menjadi Guru Inspiratif, Kreatif, danInovatif. Yogyakarta: DIVA Press.

Marlina. (2007). Asesmen Dan Strategi Intervensi Anak ADHD (Attention Deficit Hyperactivity Disorders). Jakarta: Departemen Pendidikan Nasional.

Noorlaia, Iva. (2010). Panduan Lengkap Mengajar PAUD. Yogyakatra: Pinus.

Rahardjo, Budi. (2009). “Optimalisasi Kecerdasan Interpesonal Anak Usia Dini di TK \& Kel. At-Taqwa Rawamangun", Tesis, Jakarta: Pascasarjana Universitas Jakarta.

Ranggiasanka, Aden. (2011). Serba-Serbi Pendidikan Anak. Yokyakarta: Siklus.

Ratih, \& Afin Murtiningsih. (2013). Kiat Sukses Mengasuh Anak Berkebutuhan Khusus. Yogyakarta :Ar-Ruzz Media.

Sugiyono. (2010). Metode Penelitian Pendidik Pendekatan Kualitatif, Kuantitatif, dan $R n D$. Bandung: Alfabeta

Suharmini, T. (2005). Penanganan anak hiperaktif. Jakarta: Direktorat Pembinaan Pendidikan Tenaga Kependidikan Dan Ketenagaan Perguruan Tinggi. Di akses tanggal 26 Desember 2019

Suyadi, dah Ulfah, Mauidya. (2013). Konsep Dasar Paud. Bandung : PT Remaja Rosdakarya.

Yamin \& Jamilah Sabri Sanan. (2010). Panduan Pendidikan Anak Usia Dini. Jakarta :GaungPersada.

Zakapedia. (2014). "Pengertian Peran" (online) http://wwww.artikelsiana.com/ 2014/10/pengertian-peran-definisi-fungsi-apa-itu.html? $m=1$. diakses tanggal 15 Maret 2017. 